\section{Trinucleotide repeat polymorphism at the human insulin-like growth factor I receptor gene (IGF1R)}

R.Meloni, F.Fougerousse, C.Roudaut and J.S.Beckmann Centre d'Etude du Polymorphisme Humain, 27 rue Juliette Dodu, 75010 Paris, France

Source/Description: The polymorphism is a trinucleotide repeat of the form (AGG) 7 and starts at position 967 of the human insulin-like growth factor I receptor gene on chromosome 15q25qter (GenBank accession no. M69229) (1). The polymorphism can be typed using the polymerase chain reaction (PCR) as previously described (2). The predicted size of the amplified sequence is $96 \mathrm{bp}$.

Primer Sequences:

GCTGAGGGAGGAGGCGGC (CA strand)

GGCGAGGGGCAGAAACGC (TG strand)

Frequency: Estimated from 90 chromosomes of unrelated CEPH individuals. Observed heterozygosity is $44 \%$ with a PIC of 0.35 .

$\begin{array}{lll}\text { Allele } & \text { (bp) } & \text { Frequency } \\ \text { C1 } & 96 & 0.01 \\ \text { C2 } & 93 & 0.69 \\ \text { C3 } & 90 & 0.30\end{array}$

Mendelian Inheritance: Co-dominant segregation was observed in three large CEPH families.

Chromosomal Localization: The human IGF1R gene has been assigned to chromosome 15q25-qter (3).

PCR Conditions: The PCR reaction was performed using $200 \mathrm{ng}$ genomic DNA, 10 pMoles of each primer, 1.5 units of Taq polymerase and $2.5 \%$ formamide in a final volume of $50 \mu \mathrm{l}$. Samples were subjected to 30 cycles consisting of 40 seconds at $92^{\circ} \mathrm{C}, 30$ seconds at $63^{\circ} \mathrm{C}$ and 30 seconds at $72^{\circ} \mathrm{C}$.

Acknowledgements: This work was supported by Grants from Genethon and Association Francaise contre les Myopathies.

References: 1) Cooke,D.W. et al. (1991) Biochem. Biophys. Res. Comm. 177, 1113-1120. 2) Weber,J.L. and May,P.E. (1989) Amer. J. Hum. Genet. 44, 388-396. 3) Francke, U. et al. (1986) Cold Spring Harbor Symp. Quant. Biol. 51, 855-866.

\section{Trinucleotide repeat polymorphism in the androgen receptor gene (AR)}

H.F.B.M.Sleddens, B.A.Oostra', A.O.Brinkmann² and J.Trapman *

Departments of Pathology, ' ${ }^{1}$ Cell Biology \& Genetics'and 2Endocrinology \& Reproduction, Erasmus University, PO Box 1738, 3000 DR Rotterdam, The Netherlands

Source/Description: The human androgen receptor gene contains in exon one a $(\mathrm{CAG})_{\mathrm{N}}(\mathrm{CAA})$ repeat, encoding a polyglutamine stretch, at position 172 following the translation start codon (1). This polymorphism is extremely useful for diagnosis in families with the Androgen Insensitivity Syndromes, which display a high incidence of distinctive mutations in the androgen receptor gene $(2-5)$. The polymorphism could be typed using the polymerase chain reaction (PCR). The length of the repeat in allele $B 10$ was $(\mathrm{CAG})_{19}(\mathrm{CAA})$.

Primer Sequences:

Forward 5'TCCGCGAAGTGATCCAGAAC Reverse 5'CTTGGGGAGAACCATCCTCA

Frequency: Eleven different allele products were detected among 63 chromosomes of 22 female and 19 male, unrelated Caucasians. The heterozygosity in females is $\mathbf{0 . 8 9}$.

$\begin{array}{llllll}\text { Allele } & \text { (bp) } & \text { Frequency } & \text { Allele } & \text { (bp) } & \text { Frequency } \\ \text { B11 } & 195 & 0.03 & \text { B5 } & 213 & 0.13 \\ \text { B10 } & 198 & 0.17 & \text { B4 } & 216 & 0.11 \\ \text { B9 } & 201 & 0.11 & \text { B3 } & 219 & 0.03 \\ \text { B8 } & 204 & 0.16 & \text { B2 } & 222 & 0.03 \\ \text { B7 } & 207 & 0.08 & \text { B1 } & 225 & 0.02 \\ \text { B6 } & 210 & 0.13 & & & \end{array}$

Chromosomal Location: The androgen receptor gene (AR) has been assigned to Xq11-12 (6).

Other Comments: 200 ng of genomic DNA was amplified using $60 \mathrm{ng}$ of each primer and $0.02 \mathrm{U}$ Super Taq DNA polymerase (HB Technology, Cambridge) in a total volume of $15 \mu \mathrm{l}$ in a buffer, containing $50 \mathrm{mM} \mathrm{KCl}, 1.5 \mathrm{mM} \mathrm{MgCl}_{2}, 0.1 \%$ Triton $\mathrm{X}-100,0.2 \mathrm{mM}$ of dATP, dCTP, dGTP and TTP each, and $10 \mathrm{mM}$ Tris- $\mathrm{HCl}$ (pH 8.8), supplemented with $2.5 \mu \mathrm{Ci}$ [alpha- ${ }^{32} \mathrm{P}$ ]dATP. Conditions for amplification: 30 cycles of 1 minute $95^{\circ} \mathrm{C}, 2$ minutes $55^{\circ} \mathrm{C}$, and 2 minutes $72^{\circ} \mathrm{C}$. The final elongation cycle was 10 minutes at $72^{\circ} \mathrm{C}$. The radioactive amplification products were analyzed on a $6 \%$ denaturing polyacrylamide sequencing gel.

Acknowledgements: This study was supported by a grant from the Dutch Cancer Foundation (KWF).

References: 1) Faber,P.W. et al. (1989) Mol. Cell. Endocrinol. 61, 257-262. 2) Griffin,J.E. and Wilson,J.D. (1980) New Engl. J. Med 302, $198-209$. 3) Pinsky,L. and Kaufman,M. (1987) Adv. Hum. Genet. 16, 299-472. 4) Ris-Stalpers, C. et al. (1991) Mol. Endocrinol. 5, 1562-1569. 5) McPhaul,M.J. et al. (1991) J. Clin. Invest. 87, 1413-1421. 6) Brown,C.J. et al. (1989) Am. J. Hum. Genet. 44, 264-269.

* To whom correspondence should be addressed 